\title{
Observational study of influence of aerosol hygroscopic growth on scattering coefficient over rural area near Beijing mega-city
}

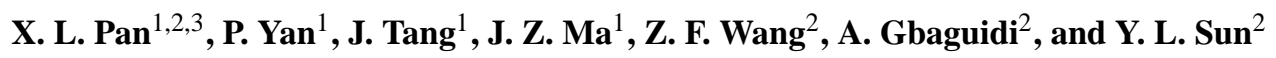 \\ ${ }^{1}$ Chinese Academy of Meteorological Science, China Meteorological Administration, Beijing, China \\ ${ }^{2}$ Nansen-Zhu International Research Centre, Institute of Atmospheric Physics, Chinese Academy of Sciences, Beijing, China \\ ${ }^{3}$ Graduate University of Chinese Academy of Sciences, Beijing, China
}

Received: 25 December 2008 - Published in Atmos. Chem. Phys. Discuss.: 25 February 2009

Revised: 26 July 2009 - Accepted: 30 July 2009 - Published: 9 October 2009

\begin{abstract}
We investigated aerosol hygroscopic growth property and its influence on scattering coefficient using M9003 nephelometers in coupling with humidity controlled inlet system at a rural site near Beijing mega-city from 24 April to 15 May 2006. Inlet relative humidity was controlled in an increasing range of $40 \%-90 \%$ while aerosol hygroscopic growth factor of scattering coefficient, $f(\mathrm{RH}=80 \%)$ as ratio of scattering coefficient at $\mathrm{RH}=80 \%$ to "dry" scattering coefficient $(\mathrm{RH}<40 \%)$ varied in a range of $1.07-2.35$ during the measurement. Further analysis indicated that under dust episode, measured $f(\mathrm{RH}=80 \%)$ is $1.2 \pm 0.02$, and estimated periodic mean value of $f(\mathrm{RH}=80 \%)$ was $1.31 \pm 0.03$ under clean periods; during urban pollution periods, the aerosol displayed relative strong water absorbing properties with $f(\mathrm{RH}=80 \%)$ of about $1.57 \pm 0.02$. An examination of chemical composition of daily filter samples highlighted that aerosol hygroscopicity was generally depressed with the increasing ratio of organic matter (OMC)/ammonium sulfate (AS) in particle mass, similar with the results of many previous studies. However, a special case with high value of $f(\mathrm{RH}=80 \%)=2.21$ and high OMC/AS ratio was also observed, this exception reflected physico-chemical particularities of organic matter and its complex interaction with other compounds during this episode.
\end{abstract}

\section{Introduction}

Aerosol hygroscopic growth with increasing relative humidity $(\mathrm{RH})$ may lead to dramatic changes in its mass concentration, size distribution and corresponding optical properties (scattering coefficient, single scattering albedo, asym-

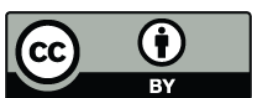

Correspondence to: J. Tang

(tangj@cams.cma.gov.cn) metry factor, etc.), which could enhance the cooling effect of aerosols in the atmosphere by directly scattering more light radiation (Carrico et al., 1998, 2000; Kotchenruther et al., 1998; Randles et al., 2004), or change cloud microphysical properties (Crumeyrolle et al., 2008) by serving as cloud condensation nuclei (CCN) (Houghton et al., 2001). To precisely evaluate the direct radiative forcing, light scattering coefficient $\left(\sigma_{s p}\right)$ of aerosol particles and its dependency on relative humidity $(\mathrm{RH})$, defined as $f(\mathrm{RH})=\sigma_{s p}$ (scanning $\mathrm{RH}) / \sigma_{s p}(\mathrm{dry})$, have been investigated for decades through Integrating Nephelometers equipped with humidity control devices in clean background regions, marine boundary layers, rural and urban areas (Kotchenruther et al., 1999; Malm et al., 2001, 2005; Carrico et al., 2003; Magi et al., 2003; Kim et al., 2006). Previous studies reported that different types of aerosol particles usually have distinct hygroscopic growth properties (Tang, 1996; Cruz et al., 2000; Kim et al., 2006). Hand and Malm (2006) indicated that the scattering coefficients of $\left(\mathrm{NH}_{4}\right)_{2} \mathrm{SO}_{4}$ and $\left(\mathrm{NH}_{4}\right) \mathrm{HSO}_{4}$ aerosols could be enhanced by a factor of three when relative humidity is over $85 \%$. Dust particles, dominant in coarse mode, are mostly insoluble with $f(\mathrm{RH}=80 \%)$ smaller than 1.1 (Li-Jones et al., 1998), but they could also be hygroscopic when coated by sulfate or other soluble inorganic aerosols during transportation (Perry et al., 2004; Shi et al., 2007). During the period of Aerosol Characterization Experiment (ACE-Asia), dust particle's hygroscopic factor of $f(\mathrm{RH}=80 \%)=1.25$ was observed in Ron Brown cruise (Carrico et al., 2003), and even as high as 2.0 in Korea (Kim et al., 2006). Combustionemitted smoke organic matter and photochemical formed organic compounds, accounting for a significant proportion of particulate aerosols, could be hygroscopic or hydrophobic depending on the types of organics and their oxidation status in the atmosphere. Studies (Carrico et al., 2005) conducted in the Yosemite National Park indicated an inverse relationship between the ratio of organic carbon mass to

Published by Copernicus Publications on behalf of the European Geosciences Union. 
$\left(\mathrm{NH}_{4}\right)_{2} \mathrm{SO}_{4}(\mathrm{OMC} / \mathrm{AS})$ and the hygroscopicity of aerosols. Researches carried out by Malm et al. (2005) in the same location showed that $f(85<\mathrm{RH}<90)$ decreased from 2.0 to $<1.2$ as OMC/AS increased from 0.57 to 11.15 . Nevertheless, inorganic aerosols' hygroscopicity enhanced by organic acids were also observed in some studies (Cruz et al., 2000; Choi et al., 2002). Therefore, following the great temporal and spatial variations of aerosols' hygroscopic growth properties, in situ and laboratory investigations are needed.

Another methodology, taking advantage of H-TDMA (Hygroscopicity-Tandem Differential Mobility Analyzer) to measure alteration of aerosol size distribution after particle hygroscopic growth has been detailed described in many studies (Chen et al., 2003; Carrico et al., 2005; Santarpia et al., 2005; Herich et al., 2008). Diameter hygroscopic growth, (referred as $\mathrm{GF}_{D}$ ) was investigated for diverse aerosol types, including urban pollutant (Chen et al., 2003; Ferron et al., 2005; Gysel et al., 2007), rural (Ferron et al., 2005; Aklilu et al., 2006), Biogenically dominated (Rissler et al., 2004) and Remote Marine aerosols (Berg et al., 1998; Zhou et al., 2001) as well as "pure" substances such as laboratory generated inorganics (Gysel et al., 2002), fresh mineral dust (Vlasenko et al., 2005), biomass burning exhausts (Pagels et al., 2003), humic-like substances (Dinar et al., 2007) and organic acids (Wise et al., 2003), etc.

In the past two decades, rapid economy growth triggered China's annual GDP reaching over 9\%, growing number of mega-cities (population over 10 millions), and increasing number of private cars (http://www.stats.gov.cn/), and consequently, the country become an important source of pollutants and aerosols production. Aerosols mass concentrations and their optical properties must have changed to some extent. In such condition, providing in sights into aerosols optical properties and its dependence on relative humidity in some Chinese key regions seems to be an important scientific issue to better understand the relationships between aerosols and climate. Previously, studies of Yan et al. (2008) at Shangdianzi (SDZ), a baseline air pollution monitoring station of North China, showed that the $f(\mathrm{RH}=80 \%)$ was 1.2 in clean air conditions and 1.48 during pollution episodes. Kim et al (2006) obtained higher value of 2.75 during the ACEAsia period. Experiment carried out in the Pearl River Delta (PRD) region (Liu et al., 2007) also indicated the urban pollutants aerosols hygroscopic growth factor $f(\mathrm{RH}=80 \%)$ of about 2.04 for Guangzhou.

The present analysis of the aerosol scattering hygroscopic factors $\mathrm{f}(\mathrm{RH})$ over the rural area near Beijing mega-city is based on an observational experiment performed from 24 April to 15 May 2006. The main purpose of this study is to investigate the characteristics of aerosol scattering properties and its dependency on the relative humidity $\mathrm{f}(\mathrm{RH})$. The effect of aerosol chemical composition, meanwhile influence of origin and mixing process during transportation with air mass back trajectory analysis will be also discussed.

\section{Experiment and instrumentation}

\subsection{Site description and meteorology}

Measurements of aerosol scattering coefficient, $f(\mathrm{RH})$, and aerosol chemical compositions were conducted at Xin'An weather operational station in Baodi county (referred simply as Xin'An site, $39.73^{\circ} \mathrm{N}, 117.51^{\circ} \mathrm{E}$, altitude: $6 \mathrm{~m}$ ) located in the rural areas of Jing-Jin-Tang region (Fig. 1). Baodi is a major agricultural district (region) of Northern China where rice and corn are cultivated. The principal human economical activities are farming and tree growing. This site which is about $85 \mathrm{~km}, 70 \mathrm{~km}$ and $105 \mathrm{~km}$ far from Beijing, Tianjin and Tangshan respectively, seems to be strongly under mega-cities air pollution influence. During the observation, meteorological condition was characterized by clear and sunshiny days, except the floating dust event at approximately 16:00 LST (Local Standard Time) 30 April. Air temperature average of experimental period was $16.1^{\circ}$, and relative humidity about $52.9 \%$, and surface wind direction at the Xin'An site was dominated by NW and E with wind speed less than $5 \mathrm{~m} / \mathrm{s}$. The observation site was particularly frequently likely influenced by anthropogenic perturbed air masses from industrial areas of Beijing and Tangshan City (Fig. 1).

\subsection{Measurement of aerosol scattering hygroscopicity}

\subsubsection{Integrating nephelometer}

Aerosol scattering coefficient $\left(\sigma_{s p}\right)$ was measured with M9003 integrating nephelometer at $525 \mathrm{~nm}$ wavelength with light integrating angle $10^{\circ}-170^{\circ}$. The measurement range of this instrument is $0-2000 \mathrm{Mm}^{-1}\left(1 \mathrm{Mm}^{-1}=10^{-6} \mathrm{~m}^{-1}\right)$ with its lower detection limit of about $0.3 \mathrm{Mm}^{-1}$ (lower than one tenth of Rayleigh scattering of air molecules), detailed information about this instrumentation have been described in many previous studies (Liu et al., 2007; Yan et al., 2008). During the experiment, a water-proof wire strainer was mounted in the head of inlet tube, and the ambient air was inhaled into nephelometer measuring chamber through $1.5 \mathrm{~m} \mathrm{1/4^{ \prime \prime }}$ anti-static tube, air temperature and relative humidity were measured by sensor in the front of the measuring cavity.

\subsubsection{Humidity control device}

The dependency of increase of aerosol scattering coefficient on relative humidity, $f(\mathrm{RH})$, is represented by the ratio of aerosol scattering coefficient at conditioned RH (from $<40 \%$ to $90 \%$ ) and that under the reference "dry" conditions (usually with $\mathrm{RH}<40 \%$ ). This method was initially introduced by Covert et al. (1972). Relative humidity of Inhaled air was regulated by a connected heating tube and humidifier. Schematics of humidifier is similar with studies at Earth System Research Laboratory, National Ocean \& Atmospheric 
Administration, USA(NOAA/GMD) (http://www.esrl.noaa. gov/gmd/aero/instrumentation/humid.html). The Humidifier consists of a deionized water bath in sheath plexiglass pipe and a water-vapor penetrating membrane tube immerged through it. The water Vapor permeated to mix with sample air was modulated by controlling of the water temperature with power of heating equipment. Conditioned relative humidity and temperature of inflow air were measured with a build-in sensor in the nephelometer.

\subsubsection{Experimental procedure and quality control}

During the observation period, the nephelometers were calibrated with the zero gas (dry filtered air) every $24 \mathrm{~h}$, and with the standard calibration gas (HFC-134a) every 7 days. The data were automatically recorded every $5 \mathrm{~min}$. Additional test on humidity sensor and dry scattering measurements were performed. The comparison of humidity sensors of two nephelometers with HMP41/45 Visala humidity indicator showed in good agreement with the difference less than $3 \%$. Measurement of $f(\mathrm{RH})$ has been obtained using two nephelometers in conjunction with two inlet in parallel; one nephelometer was kept inflow air mass in dry condition $(\mathrm{RH}<40 \%)$ through its built-in heating tube, while another regulated the sampled air $\mathrm{RH}$ from $<40 \%$ to $90 \%$ using humidity control device. In spite of well maintenance of the nephelometers, there still occasionally subsisted some discrepancy between the measured signals of two nephelometers when $\mathrm{RH}<40 \%$, that probably due to drifting electronic signal of Photomultiplier or disturbance of inlet tube. We firstly removed the periodic data of bias more than $20 \%$, and then normalized the signals to make sure $f(\mathrm{RH}<40 \%)$ was set to one (Day et al., 2000). Comparison results of two integrating nephelometers are showed in the Fig. 2. After these processes, hygroscopic growth factor of aerosol scattering coefficient could be determined, as showed in Eq. (1),

$$
f(\mathrm{RH}=80 \%)=\sigma_{s p}(\mathrm{RH}=80 \%) / \sigma_{s p}(\mathrm{RH}<40 \%)
$$

The changing ratio of scattering coefficient obtained by two nephelometers with $\mathrm{RH}$ are then fit into the following empirical equation.

$f(\mathrm{RH})=1+\mathrm{a}(\mathrm{RH} / 100)^{\mathrm{b}}$

\subsection{Aerosol sampling and chemical analysis}

Ambient aerosol particles were collected by filters using two sets of Andersen size-segregated impactors (KA200), the cut-off size ranges are: $<0.43 \mu \mathrm{m}, 0.65-0.43 \mu \mathrm{m}, 1.1-$ $0.65 \mu \mathrm{m}, 2.1-1.1 \mu \mathrm{m}, 3.3-2.1 \mu \mathrm{m}, 4.7-3.3 \mu \mathrm{m}, 7-4.7 \mu \mathrm{m}$, 11-7 $\mu \mathrm{m}$ and $>11 \mu \mathrm{m}$, respectively. Teflon membranes were used as impaction substrates (collecting water soluble inorganic samplings) for the top eight stages, and Zeflour membranes (Pall Corporation) were for the backup filter (the bottom stage). Organic carbon matter was sampled with Quartz

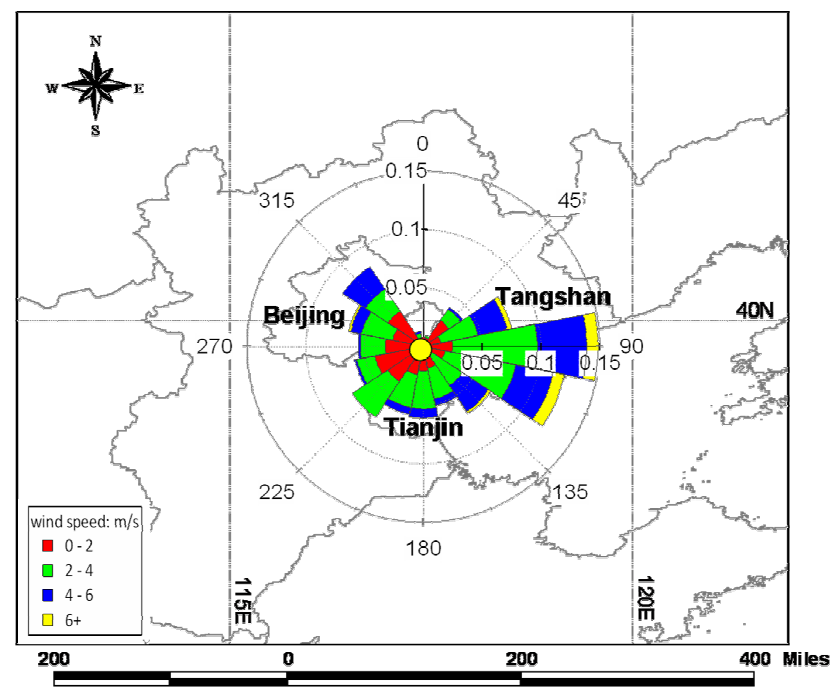

Fig. 1. Geographic location of observation site (Xin'an) with the wind rose during the experiment period.

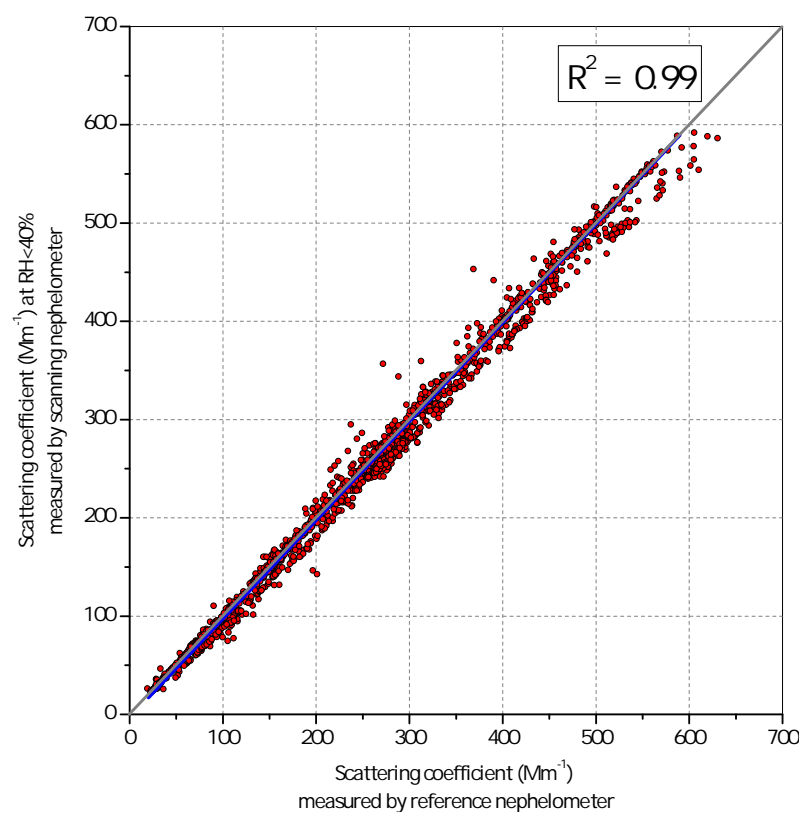

Fig. 2. Comparison of scattering coefficient measured by both reference nephelometer and scanning- $\mathrm{RH}$ nephelometer at $\mathrm{RH}<40 \%$.

membranes (Whatman QMA). The mass flow controller was used to maintain a stable flow rate at $28.3 \mathrm{~L} / \mathrm{min}$ during the sampling period, and the flow rate check was performed with a dry gas rotemeter before and after each sampling cycle. The sampling generally started at 08:30 LST (Local Standard Time), and sampling intervals were more than $22 \mathrm{~h}$. The inlet height was $2.5 \mathrm{~m}$ above ground level. Quartz filters was pretreated at temperature of $600^{\circ}$ in laboratory for $4 \mathrm{~h}$ before sampling, and the sampled filters were stored in a refrigerator at $-20^{\circ}$ at the site before they were sent to the laboratory 
for analysis. Collection period of organic samplings were on 3, 4, and 10 to 15 May, and aerosol mass concentration and inorganic samplings were performed from 24 April to 15 May (Table 1).

Aerosol mass concentrations were determined by means of weighting filters with Satorius microbalance (precision: $10 \mu \mathrm{g}$ ) before and after sample collection in the glove box. The filters were balanced in the glove box at a stable relative humidity $(40 \pm 2 \%)$ and temperature $\left(20 \pm 1^{\circ}\right)$ environment for about $72 \mathrm{~h}$ prior to weighting process. Each membrane was weighted three times in 2 days according to the standard procedure, and the difference of gross mass of the filter weighted each time was less than $50 \mathrm{ng}$.

Inorganic anions $\left(\mathrm{F}^{-}, \mathrm{Cl}^{-}, \mathrm{NO}_{3}^{-}, \mathrm{SO}_{4}^{2-}\right)$ was analyzed with Dionex 500 ion chromatography (IC), and cations $\left(\mathrm{NH}_{4}^{+}, \mathrm{K}^{+}, \mathrm{Na}^{+}, \mathrm{Ca}^{2+}, \mathrm{Mg}^{2+}\right)$ with HITACHI $180-70$ flame atomic absorption spectrophotometer (FAAS) following standard operation procedure at the Key Laboratory of Atmospheric Chemistry, China Meteorological Administration (CMA). Organic carbon (OC) was analyzed using thermal/optical carbon analyzer (Sunset Lab) at the Center of Environment, Peking University, and the precision and detection limits (LDC) are $10 \%$ and $2 \mu \mathrm{g} \mathrm{cm}^{-2}$, respectively.

\section{Result and discussion}

\subsection{Classification of different observation periods}

During spring over Northern China, aerosol chemical properties are rather complex because of the mixture of different sources including transportation of heavy air pollution from urbanization and industrial activities, desert dust particles from frequent dust events, and local emitted plant organic compounds during vegetal "greening". We categorized observation periods into four different groups according to records of weather phenomena, aerosol mass concentration and 72-h air masses pathways. Air masses back trajectories were calculated by means of the Hybrid Single-particle Lagrangian Integrated Trajectory (HYSPLIT) model (Draxler et al., 1998). Meteorological fields with 3-h time interval (formatted as GDAS) were obtained from US National Centers for Environmental Prediction (NECP). The back trajectory starting geographical position was located at Xin'An site with starting altitude of $100 \mathrm{~m}$. The procedure of dissociation of different periodicity can be described as follows:

1. Detect period influenced by pronounced dust aerosols in accordance with observational records and 3-h meteorological information (Provided by China Meteorological Administration, CMA). The floating dust episode occurred in the afternoon of 30 April (approximately 17:00 LST) while the local visibility was less than $1 \mathrm{~km}$. 72-h back trajectories shows that air masses are originated from central Mongolia and past through Hunshandake desert before arriving at Xin'An site.
2. Select the periods where mass concentration of fine particles $\left(\mathrm{PM}_{2.1}\right.$, particle diameter less than $\left.2.1 \mu \mathrm{m}\right)$ are less than $50 \mu \mathrm{g} \cdot \mathrm{m}^{-3}$ as "clean periods", and use this value as delimitation of clean-to-pollution on the ground where the value is approximately equivalent to Air Pollution Index (http://www.mep.gov.cn/) of about 50 (indication of "good" air quality), and back trajectories shows incoming air masses have not passing through anthropogenic sources with probable pollutant emission for $72 \mathrm{~h}$.

3. Concerning the geographic location of Xin'An, observation site located right in the center of three pollution source areas, Beijing, Tianjin and Tangshan (shown in Fig. 1), and urban emitted anthropogenic pollutants might be easily transported to the site, here we choose the periods when $\mathrm{PM}_{2.1}$ mass concentrations over $50 \mu \mathrm{g} \cdot \mathrm{m}^{-3}$ as influenced by regional urban pollutions. Back trajectories analysis also indicates that most of air masses came from the pollutant area of nearby regions in prevail of southern wind, and there are also some periods when air masses were stationary over Beijing and Hebei provinces under synoptic high pressure weather system.

\subsection{Chemical and physical characteristics of ambient aerosols}

\subsubsection{Mass concentration}

Statistic analysis results show that average concentrations of $\mathrm{PM}_{2.1}$ and that of $\mathrm{PM}_{11}$ (particle diameter less than $11 \mu \mathrm{m}$ ) are $81.01 \mu \mathrm{g} \cdot \mathrm{m}^{-3}$ and $214.3 \mu \mathrm{g} \cdot \mathrm{m}^{-3}$ with standard deviation of $32.76 \mu \mathrm{g} \cdot \mathrm{m}^{-3}$ and $125.3 \mu \mathrm{g} \cdot \mathrm{m}^{-3}$, respectively. Apart from this special period of dust event, the percentage of $\mathrm{PM}_{2.1} / \mathrm{PM}_{11}$, is averagely $0.42 \pm 0.11$ with minimum value of 0.27 and maximum of 0.65 , which is reasonable and similar with the observation results $\left(\mathrm{PM}_{2.5} / \mathrm{PM}_{10}=0.47 \pm 0.17\right)$ carried out in the suburban area of Beijing (Sun et al., 2004). Chen et al. (2005) also reported mean value of 0.44 ranging from $0.37 \sim 0.53$. Organic carbon accounts for the largest percentage of aerosols masses of both $\mathrm{PM}_{2.1}$ and $\mathrm{PM}_{11}$ with mean values (standard deviation) of $13.6(9.4) \mu \mathrm{g} \cdot \mathrm{m}^{-3}$ and $31.3(17.4) \mu \mathrm{g} \cdot \mathrm{m}^{-3}$. Many previous observation studies $(\mathrm{He}$ et al., 2001; Duan et al., 2004) showed an approximately same OC concentration level at the near study site (suburban of Beijing); the high OC concentration was mostly in connection with urban residential activities (Yang et al., 2005) and biomass burning (Duan et al., 2004). In $\mathrm{PM}_{2.1}$ category, mass concentration of water soluble $\mathrm{SO}_{4}^{2-}$ ion was 11.5(7.6) $\mu \mathrm{g} \cdot \mathrm{m}^{-3}$, followed by $\mathrm{NO}_{3}^{-}$and $\mathrm{NH}_{4}^{+}$ions with value of $6.05(4.52) \mu \mathrm{g} \cdot \mathrm{m}^{-3}$ and $4.02(3.17) \mu \mathrm{g} \cdot \mathrm{m}^{-3}$. This indicated anthropogenic urban pollution influence during the observation period. In the $\mathrm{PM}_{11}$, soluble $\mathrm{Ca}^{2+}$ ion makes up the second largest proportion of aerosol masses that may be 
related to flowing soil dirt during the springtime generally featured by low ambient relative humidity and strong wind.

\subsubsection{Size distribution}

Aerosol mass size-distribution displays bi-modal feature during the periods of pollutant condition (Fig. 3a), and the lower-diameter peak appears in the range of $0.33 \sim 0.47 \mu \mathrm{m}$ with mass concentration of $27 \mu \mathrm{g} \cdot \mathrm{m}^{-3}$ averagely, maximum percentage of ammonium sulfate in all detected water soluble inorganic matter accounts for $52.2 \%$ in particle size less than $0.43 \mu \mathrm{m}$ and that of ammonium nitrate is $25.1 \%$ in diameter range of $0.65 \sim 1.1 \mu \mathrm{m}$, indicating the influence of urban emission pollutant and the production of gas-to-particle formation. In the coarse mode, high concentration (averagely $33.41 \mu \mathrm{g} \cdot \mathrm{m}^{-3}$ ) of aerosol particle occurs in the diameter of $4.7 \sim 7.0 \mu \mathrm{m}$, and $\mathrm{Ca}^{2+}$ ion takes up about $47.8 \%$, it is more likely resulted from the floating dirt and crustal substances for strong wind and low ambient relative humidity during spring time (Fig. 3b).

During clean and dust influencing periods, aerosol mass concentration display mono-peak (appears in diameter of $3.3 \sim 7.0 \mu \mathrm{m}$ ) distribution, with maximum value of $28.5 \mu \mathrm{g} \cdot \mathrm{m}^{-3}$ and $179.3 \mu \mathrm{g} \cdot \mathrm{m}^{-3}$, respectively (Fig. 3a). In clean condition (Fig. 3d), the average percentage of sulfate and nitrate in fine mode $\left(<\mathrm{PM}_{2.1}\right)$ are $24.6 \%$ and $9.04 \%$, less than half values in pollutant periods. $\mathrm{Ca}^{2+}$ is most abundant materials with average percentage of $45.2 \%$ in fine mode $\left(<\mathrm{PM}_{2.1}\right)$ and $60.3 \%$ in coarse mode $\left(>\mathrm{PM}_{2.1}\right)$. During dust episode, the proportion of $\mathrm{Ca}^{2+}$ mass concentration occurs in the size range of $7.0 \sim 11.0 \mu \mathrm{m}$ with value of $74.4 \%$, and gradually decreases to averagely $17.2 \%$ in the fine mode. Percentage of sum of sulfate and nitrate arise from $16.5 \%$ $(7.0 \sim 11.0 \mu \mathrm{m})$ to $46.7 \%(<0.43 \mu \mathrm{m})$ (Fig. $3 \mathrm{c})$.

\subsection{Aerosol scattering closure calculation}

Measured mean aerosol scattering coefficient (standard deviation) in dry condition $(\mathrm{RH}<40 \%)$ for clean, dust, and pollutant periods are averagely $69.7(30.1) \mathrm{Mm}^{-1}, 376.0$ (130.3) $\mathrm{Mm}^{-1}$ and 311.2 (164.1) $\mathrm{Mm}^{-1}$. With regard to periods when both inorganic and organic samplings were collected, compared analysis has been performed between measured dry scattering coefficient and constructed ones derived from two closure calculations involving Lorenz-Mie theory (Van De Hulst, 1981; Bohren et al., 1983, 1994) and IMPROVE method (Malm et al., 2005).

Lorenz-Mie theory, analytical solution of Maxwell's equations for the scattering of electromagnetic radiation by spherical particles, provides insights into chemo-optical relationships of aerosol community in the atmosphere. During calculations, we assumed that all aerosol particles were externalmixed and in shape of perfect sphere (McMurry et al., 1996). The chemical species involved EC, OC, $\left(\mathrm{NH}_{4}\right)_{2} \mathrm{SO}_{4}$, $\mathrm{NH}_{4} \mathrm{NO}_{3}$, and water soluble ion $\left(\mathrm{F}^{-}, \mathrm{Cl}^{-}, \mathrm{Na}^{-}, \mathrm{Mg}^{2+}\right)$ and rested crustal substances; complex refractive indices and densities of species were taken from reference (Larson et al., 1988). Aerosol light scattering coefficient was integrated with aerosol number distribution and Mie scattering efficiency (derived directly from Lorenz-Mie calculation) for each particle species.

Reconstructed total ambient light scattering by particles in the Interagency Monitoring of Protected Visual Environment (IMPROVE) protocol are given by Eq. (3) in the premise of an externally mixed aerosol community, as follows:

$$
\begin{aligned}
\mathrm{b}_{\text {scat }}= & 3.0 f(\mathrm{RH})_{\text {sulfate }}[\text { Sulfate }]+3.0 f(\mathrm{RH})_{\text {Nitrate }}[\text { Nitrate }] \\
& +4.0 \mathrm{R}_{\mathrm{OC}}[\mathrm{OC}]+1.0[\text { FineSoil }]+0.6[\text { CoarseMass }]
\end{aligned}
$$

where $f(\mathrm{RH})$ is hygroscopic factor of aerosol scattering coefficient as mentioned above (it is equal to one in the dry condition), $R_{\mathrm{OC}}$ is multiplied factor to convert organic carbon to total particulate organic matter, Turpin and Lim (2001) (recommended a factor of 1.6 for urban organic aerosols, and even 2.1 for non-urban organic aerosols). According to closure result in Yosemite Nation Park, $R_{\mathrm{OC}}$ value of 1.8 allowed for fine mass closure in both biomass burning and regional haze conditions (Malm et al., 2005), and we took value of 1.8 for calculation as IMPROVE suggested (http: //vista.cira.colostate.edu/improve/Publications/GrayLit/ 016_IMPROVEeqReview/IMPROVEeqReview.htm) hereafter. The mass concentration of chemical compositions in $\mathrm{PM}_{2.1}$ was used in closure calculation under the assumption that fine particles contribute large portion of scattering, and this hypothesis has been supported by the Lorenz-Mie theory results (estimated contribution of $\mathrm{PM}_{2.1}$ scattering effect to total scattering coefficient averagely $80.6 \%$ in this study) and previous studies (Meszaros et al., 1998).

Calculation results of two closure methods mentioned above are displayed in Fig. 4. The scattering coefficients closures show good agreements to the measurements, with $R^{2}$ of 0.89 and 0.82 for IMPROVE method and Lorenz-Mie theory method. Based on analysis of mass chemical information, relatively large discrepancy between the calculations and the measurements occurs on these days in particular under coarse particles high concentrations condition. Local perturbed aerosols arise from agriculture activities may be a plausible explanation. In fact, some soil tillage occurred near the site within $100 \mathrm{~m}$ in distance according to meteorological and aerosol observation records.

\subsection{Distinction of different scattering hygroscopicity}

Measured aerosol scattering growth feature with relative humidity is showed in Fig. 5. All the $f(\mathrm{RH})$ displayed a similar appearance in the general shape of the hygroscopic growth (monotonic increasing) in spite of significant scattering of data points, and temporal variation of $f(\mathrm{RH}=80 \%)$. Different hygroscopic growth curves are categorized according to weather condition (Sect. 3.1) and high variations of chemophysical features (listed in Table 2) related to the unique 

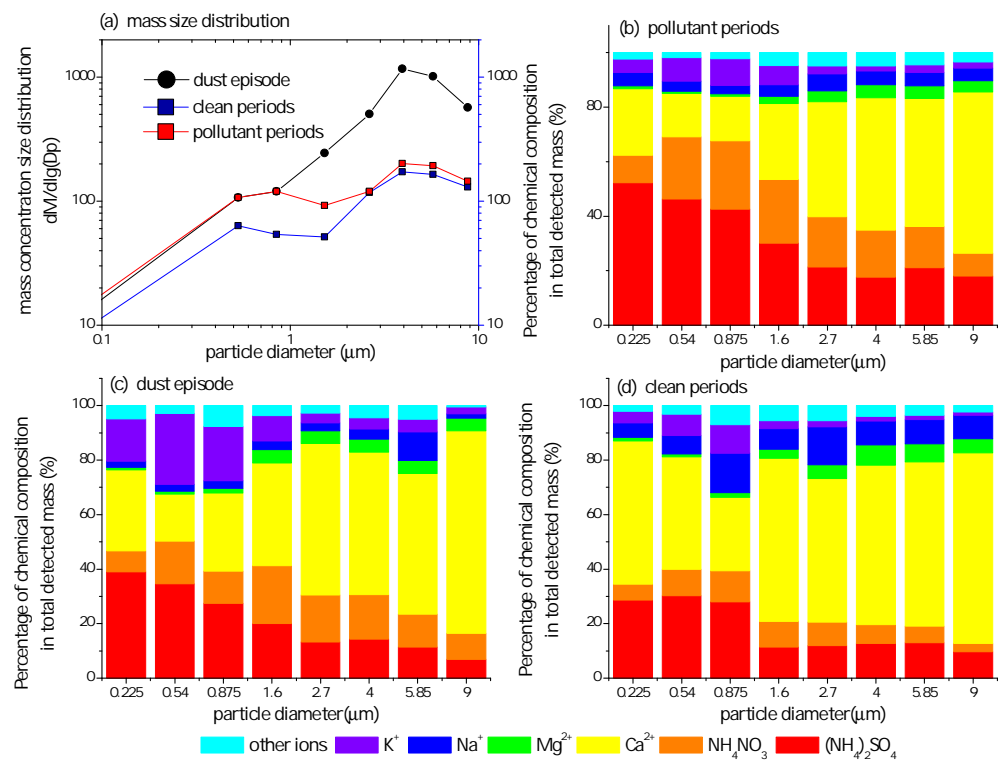

Fig. 3. Aerosol mass size distribution (a) and percentage of chemical compounds in detected water soluble inorganic during clean (b), dust (c) and pollutant (d) periods. The label diameter in the plot is arithmetic average of aerodynamic diameters. Mass concentration of $\left(\mathrm{NH}_{4}\right)_{2} \mathrm{SO}_{4}$ and $\mathrm{NH}_{4} \mathrm{NO}_{3}$ are derived from equation in reference (Malm et al., 2001).
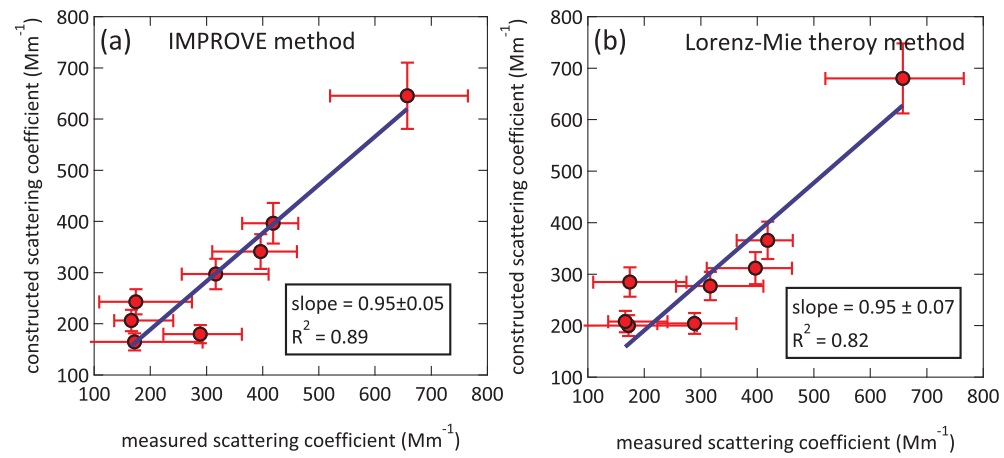

Fig. 4. Results of scattering closure calculation using both IMPROVE method (a) and Lorenz-Mie theory method (b).

Table 1. Instrumentation of measurements.

\begin{tabular}{|c|c|c|c|}
\hline Measurements & Instrumentation & Parameters & Time period \\
\hline $\begin{array}{l}\text { Scattering coefficient } \\
\left(\sigma_{s p}\right)\end{array}$ & Integrating Nephelometer & $\begin{array}{l}\text { Model M9003, Ecotech, Australia, } \\
\text { wavelength of } 525 \mathrm{~nm}\end{array}$ & 24 April to 15 May 2006 \\
\hline $\begin{array}{l}\text { Hygroscopic growth factor } \\
\text { of } \sigma_{s p}, f(\mathrm{RH})\end{array}$ & $\begin{array}{l}\text { Humidity control devices } \\
\text { and nephelometers }\end{array}$ & - & 24 April to 15 May 2006 \\
\hline Filter sampling for ions & $\begin{array}{l}\text { Multi-stage impactor, } \\
\text { with teflon membranes }\end{array}$ & Anderson KA 200 & 24 April to 15 May 2006 \\
\hline Filter sampling for OC, EC & $\begin{array}{l}\text { Multi-stage impactor, } \\
\text { with quartz membranes }\end{array}$ & 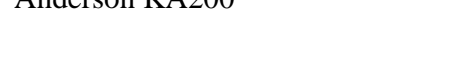 & 3, 4, and 10-15 May 2006 \\
\hline
\end{tabular}


dominant aerosols types at Xin'An site will be discussed afterwards. Comparisons with other experimental results for aerosol's hygroscopic properties in different weather conditions are listed in Table 3.

\subsubsection{Clean period}

During clean days, aerosol scattering growth features with relative humidity, showed large temporal variations (Fig. 5) with averaged measured of $f(\mathrm{RH}=80 \%)=1.31$ (Table 2), corresponding to about $10 \%$ higher than $(f(\mathrm{RH}=80 \%)=1.2)$ indicated by Yan et al. (2009) for another rural site $(100 \mathrm{~km}$ northeast far from Xin'An site) of north Beijing, and about $8.1 \%$ and $24.1 \%$ lower than the results $(f(\mathrm{RH}=80 \%)=1.42)$ reported by Koloutsou-Vakakis et al. (2001) for the Northern Hemisphere continental site (Bondville, Illinois, US) and $(f(\mathrm{RH}=80 \%)=1.67)$ measured by Carrico et al. (2000) in the clean air conditions in Sagres (Portugal, ACE-2) respectively (Table 3 ). In clean days, site prevails northerly wind and mean mass concentration of $\mathrm{PM}_{2.1}$ and ammonium sulfate are $43.5 \mu \mathrm{g} \cdot \mathrm{m}^{-3}$ and $6.4 \mu \mathrm{g} \cdot \mathrm{m}^{-3}$, respectively (Fig. 3d), dry scattering coefficient is averagely $89.2 \mathrm{Mm}^{-1}$. In Bondville site, aerosol scattering coefficient is averagely only $33.4 \mathrm{Mm}^{-1}$ during spring time, comparably lower than the result in surrounding area of Beijing, however local high proportion of sulfate burden in $\mathrm{PM}$ and $\mathrm{SO}_{2}$ concentration, reported by Charlson et al. (1991) and Harris et al. (1994) might be the possible contributions to relatively higher $f(\mathrm{RH}=80 \%)$. According to the results in Sagres, lower dry $(\mathrm{RH}<30 \%)$ scattering coefficient of aerosol (only $19.4 \pm 8.9 \mathrm{Mm}^{-1}$ for $\mathrm{PM}_{10}$ during clean period) related with different aerosol physical chemical properties could partially account for that discrepancies. Studies of Yan et al. (2009) were performed in the baseline air monitoring station of Northern China, where geographical environment within 30 $\mathrm{km}$ radius distance was characterized by rolling hills farmland, orchard and forests with lower pollutants concentrations and scattering coefficient (averagely $30 \mathrm{Mm}^{-1}$ ).

\subsubsection{Dust period}

Measured $f(\mathrm{RH}=80 \%)$ was averagely 1.20 in the dust episode. This value seemed to be close to the results obtained by Carrico et al. (2003), of which $f(\mathrm{RH}=82.5 \%)$ were 1.18 and 1.39 for particles size less than $10 \mu$ and $1 \mu \mathrm{m}$ respectively in East Asia (ACE-Asia) during dust dominant period. Observational experiment performed by Kim et al. (2006) in Kosan (South Korea) indicated aerosol $f(\mathrm{RH}=85 \%)=1.73$ 2.20 during dust episode (Table 3). They reported the aerosol dry scattering coefficient of $238.6 \mathrm{Mm}^{-1}$, only $33.7 \%$ of value in Beijing. These differences might be resulted from the mixing effect of dust particles with other inorganic materials during transportation. This is supported by many previous studies on dust particles over marine (Yamato et al., 1994; Zhang et al., 2003) or urban areas (Zhang et al., 1999;

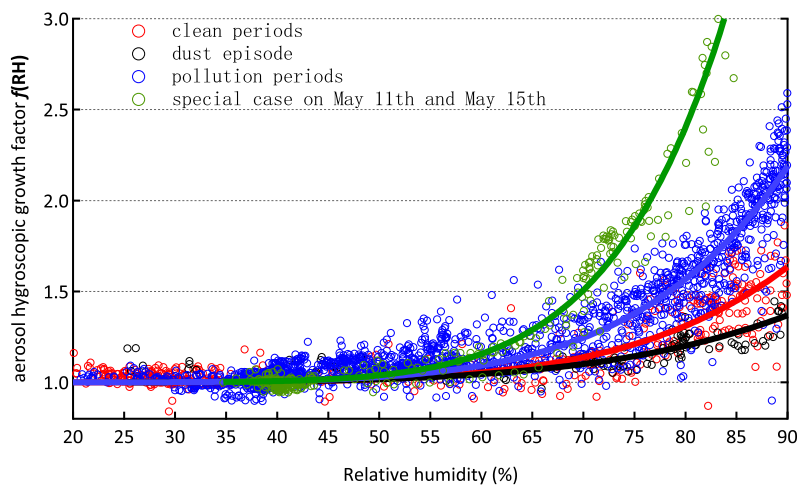

Fig. 5. Fitting curves of different dominant aerosol types. Among them, dot data represent the measurement results and lines stand for the fitting output of Eq. (2) for different aerosol types. Black, red, blue and green refer to the results of dust, clean, urban pollution and special case for urban pollution episodes, respectively.

Wang et al., 2007) of which the authors demonstrated that the mixing of sulfate, nitrate, and coarse calcium in dust particles could substantially enhance the hygroscopicity. coarse calcium dust particles with nitrate-containing could appears in aqueous phase even at 15\% RH (Shi et al., 2007).

\subsubsection{Pollution episode}

Under urban anthropogenic pollutants dominance condition, humidograms showed little evidence of deliquescence but monotonic changes in scatting coefficient with increasing control RH (Fig. 5). Measured aerosol hygroscopic growth factor $f(\mathrm{RH}=80 \%)$ is 1.57 , about $6 \%$ greater than the results ( $f(\mathrm{RH}=80 \%)=1.48)$ obtained by Yan et al. (2008) for periods under the downwind of urban plum from Beijing city.

In this episode, measured dry aerosol scattering coefficient is $311.2 \mathrm{Mm}^{-1}$ (three times higher than that of clean period), mean mass concentration of $\mathrm{PM}_{2.1}$ is $87.9 \mu \mathrm{g} \cdot \mathrm{m}^{-3}$ and ratio of $\mathrm{PM}_{2.1}$ to $\mathrm{PM}_{11}$ increase from $30 \%$ (clean periods) to $42.8 \%$, percentage of sulfate and nitrate in the water soluble inorganic enhance to $42.8 \%$ and $20.4 \%$ in $\mathrm{PM}_{2.1}$ and they accounts for $63.2 \%$ of total ions (Fig. 3b), which all indicates the influence of urban emitted pollutants. Air mass back trajectory analysis show that air pathway has passed through polluted regions in Tianjin, Hebei and Shandong provinces.

Kim et al. (2006) reported approximately the same $f(\mathrm{RH}=80 \%)=1.55-1.77$ for local urban pollution (from Korea industrial area) episode in Gosan regional background site, and $f(\mathrm{RH}=80 \%)=2.0 \sim 2.43$ of pollutants from east region of China (about 26\% 43\% higher than the results). We speculate possible alteration of physico-chemical properties of aerosol particles during the transport through over the East Chinese Sea in terms of the measured aerosol single scattering albedo $(0.89 \pm 0.02)$. The latter is higher than results reported by Bergin et al. (2001) in urban area of Beijing (0.81) and those of Yan et al. (2008) and Qiu et al. (2004) in background monitor station in North China (0.85) and in 
Table 2. Designation of different dominant types of aerosols.

\begin{tabular}{lllrrrrrr}
\hline Episode & Dominant aerosols & Wind direction & $\begin{array}{r}\mathrm{PM}_{2.1} \\
\mu \mathrm{g} \cdot \mathrm{m}^{-3}\end{array}$ & $\begin{array}{r}\mathrm{PM}_{2.1} / \mathrm{PM}_{11} \\
\%\end{array}$ & $\begin{array}{r}\sigma_{s p} \\
\mathrm{Mm}^{-1}\end{array}$ & $\begin{array}{r}\mathrm{AS} \mathrm{S}^{\mathrm{a}} \\
\mu \mathrm{g} \cdot \mathrm{m}^{-3}\end{array}$ & $\begin{array}{r}\mathrm{Mean} f(\mathrm{RH}=80 \%) \\
\mathrm{N}\end{array}$ \\
\hline \multirow{2}{*}{ Dust } & Dust particles & Northwest & 128.22 & 18.5 & 707.9 & 8.44 & $1.2 \pm 0.02$ & 2 \\
Clean & $\begin{array}{l}\text { Tiny fraction of inorganic } \\
\text { and organic matters }\end{array}$ & Northerly & 43.53 & 30.0 & 89.2 & 6.39 & $1.31 \pm 0.03$ & 10 \\
Urban & $\begin{array}{l}\text { Urban anthropogenic } \\
\text { aerosols }\end{array}$ & $\begin{array}{l}\text { South/ } \\
\text { Southeast }\end{array}$ & 87.93 & 42.8 & 311.2 & 18.70 & $1.57 \pm 0.02$ & 37 \\
& & & & & & & \\
\hline
\end{tabular}

${ }^{a}$ mass concentration of ammonium sulfate in $\mathrm{PM}_{2.1}$.

Table 3. Other observation results of hygroscopic growth factor of scattering coefficient for different categories of aerosols.

\begin{tabular}{|c|c|c|c|c|c|c|}
\hline Study region (Experiment) & Period & Aerosol type & $\begin{array}{l}\text { Dry scattering } \\
\text { coefficient }^{\mathrm{a}}\end{array}$ & $f(\mathrm{RH}=80 \%)^{\mathrm{b}}$ & RH range & References \\
\hline Great Somky Mountain & & & 160 & 1.95 & $82.8 / 40$ & \\
\hline Grand Canyon & 1995 & Rural & 10 & 1.88 & $82.3 / 40$ & Day and Malm (2001) \\
\hline Big Bend & & & - & 1.93 & $82.5 / 40$ & \\
\hline Brazil (SCAR-B) & August-September 1995 & Biomass burning & - & $1.16(1.01-1.51)$ & $80 / 30$ & Kotchenruther and Hobbs (1998) \\
\hline $\begin{array}{l}\text { Bondvill, } \\
\text { Illionois }\end{array}$ & $\begin{array}{l}1995 \\
1995\end{array}$ & $\begin{array}{l}\text { Northern Hemisphere } \\
\text { continental site }\left(\mathrm{PM}_{10}\right)\end{array}$ & $\begin{array}{l}33.4 \text { in spring time } \\
64.3 \text { in summer time }\end{array}$ & 1.42 & $82.5 / 40$ & Koloutsou-Vakakis et al. $(2001)^{\mathrm{c}}$ \\
\hline Sagres, Portugal ACE-2 & 15 June-25 July 1997 & $\begin{array}{l}\text { Polluted }\left(\mathrm{PM}_{10}\right) \\
\text { Clean }\left(\mathrm{PM}_{10}\right)\end{array}$ & $\begin{array}{l}75.1 \pm 30.5 \\
19.4 \pm 8.9\end{array}$ & $\begin{array}{l}1.40 \\
1.67\end{array}$ & $82.5 / 30$ & Carrico et al. $(2000)^{\mathrm{d}}$ \\
\hline East Coast of US (TARFOX) & 10-31 July 1996 & Urban/industrial & - & $\begin{array}{l}1.81 \pm 0.37- \\
2.30 \pm 0.24\end{array}$ & $80 / 30$ & Kotchenruther et al. (1999) \\
\hline Cape Grim Tasmania ACE-1 & 15 June-25 July 1997 & Rural & $\begin{array}{l}15.4 \pm 7.9\left(\mathrm{PM}_{10}\right) \\
3.6 \pm 1.9\left(\mathrm{PM}_{1}\right)\end{array}$ & 1.89 & $82.5 / 30$ & Carrico et al. (1998)e \\
\hline Yangtze delta & $\begin{array}{l}28 \text { October- } \\
30 \text { November } 1999\end{array}$ & Urban/background & $353 \pm 202$ & $1.7-2.0$ & $85 / 40$ & Xu et al (2002) \\
\hline Southern Africa (SAFARI) & $\begin{array}{l}10 \text { August- } \\
18 \text { September } 2000\end{array}$ & Biomass burning & $340.0 \pm 290.8$ & $\begin{array}{l}1.42 \pm 0.05- \\
2.07 \pm 0.03\end{array}$ & $80 / 30$ & Magi and Hobbs (2003) \\
\hline East Asia (ACE-Asia) & 11-27 April 2001 & $\begin{array}{l}\text { Dust } \\
\text { Pollution (China) } \\
\text { Pollution (Korea) } \\
\text { Smoke }\end{array}$ & $\begin{array}{l}238.6 \pm 55.3 \\
77.0 \pm 39.6 \\
78.2 \pm 25.2 \\
137.0 \pm 39.7\end{array}$ & $\begin{array}{l}1.69-1.73 \\
2.0-2.43 \\
1.55-1.77 \\
1.30-1.59\end{array}$ & $85 / 40$ & Kim et al. (2006) \\
\hline East Asia (ACE-Asia) & March-April 2001 & $\begin{array}{l}\text { Pollution }\left(\mathrm{PM}_{10}\right) \\
\text { Marine }\left(\mathrm{PM}_{10}\right) \\
\text { Dust }\left(\mathrm{PM}_{10}\right)\end{array}$ & $64 \pm 30$ & $\begin{array}{l}2.36 \\
2.04 \\
1.25\end{array}$ & $85 / 35$ & Carrico et al. (2003) \\
\hline Pearl River Delta(PRD) & 1-31 July 2006 & $\begin{array}{l}\text { Urban } \\
\text { Mixed } \\
\text { Marine }\end{array}$ & $\begin{array}{l}- \\
- \\
-\end{array}$ & $\begin{array}{l}2.04 \pm 0.28 \\
2.29 \pm 0.28 \\
2.68 \pm 0.59\end{array}$ & $80 / 40$ & Liu et al. (2007) \\
\hline $\begin{array}{l}\text { SDZ regional Background } \\
\text { monitoring station }\end{array}$ & December 2005 & $\begin{array}{l}\text { Clean } \\
\text { Urban pollution }\end{array}$ & $\begin{array}{l}30.0 \\
286.2 \sim 380.5\end{array}$ & $\begin{array}{l}1.2 \\
1.48\end{array}$ & $85 / 40$ & Yan et al. (2009) \\
\hline $\begin{array}{l}\text { Suburban area near } \\
\text { Beijing (East Asia) }\end{array}$ & 24 April-15 May 2006 & $\begin{array}{l}\text { Dust } \\
\text { Clean } \\
\text { Urban pollution } \\
\text { Special case }\end{array}$ & $\begin{array}{l}707.9 \\
89.2 \\
311.5 \\
200.0\end{array}$ & $\begin{array}{l}1.27 \sim 1.34 \\
1.17 \sim 1.23 \\
1.55 \sim 1.59 \\
2.33 \sim 2.48\end{array}$ & $90 / 40$ & This study \\
\hline
\end{tabular}

a scattering coefficient in condition of $\mathrm{RH}<40 \%$; $\mathrm{b}$ values provide in the table is derived from the fitting formulas in the reference; ${ }^{\mathrm{c}}$ polynomial fitting form was utilized as $f(\mathrm{RH})_{s p}=I+\mathrm{A} 1^{*} \mathrm{RH}+\mathrm{A} 2^{*} \mathrm{RH}^{2}+\mathrm{A} 2^{*} \mathrm{RH}^{3}$; ${ }^{\mathrm{d}}$ fitting equation as $f(\mathrm{RH})=1+\left(\mathrm{A}_{0} /\left(1+\exp \left(\mathrm{A}_{1}^{*}\right.\right.\right.$ $\left.\left.\left(\mathrm{A}_{2}-\mathrm{RH}\right)\right)\right)$ ) under clean conditions, and $f(\mathrm{RH})=\mathrm{A} 1+\mathrm{A} 2 * \mathrm{RH}+\mathrm{A} 3^{*} \mathrm{RH}^{2}$ is used for all other cases; ${ }^{\text {e }}$ Using an Fitting equation of form $f(\mathrm{RH})=1+\left(\mathrm{A}_{0} /\left(1+\exp \left(\mathrm{A}_{1}^{*}\left(\mathrm{~A}_{2}-\mathrm{RH}\right)\right)\right)\right)$ for clean conditions.

urban area of North China (0.83) respectively. ACE-2 experiments conducted by Carrico et al. (2000) in Sagres showed that $f(\mathrm{RH}=80 \%)$ value of 1.40 for anthropogenic pollutant $\left(\mathrm{PM}_{10}\right)$ from Europe, about $6.6 \%$ lower than measured results in the present study.
Many other studies (listed in Table 3) indicated more hygroscopic properties of urban aerosols, 2.04 \pm 0.28 in PRD region (Liu et al., 2007), 1.7-2.0 in Yangtze delta region (Xu et al., 2002) and $1.81 \pm 0.37 \sim 2.30 \pm 0.24$ in the flight over east coast of the United States (Kotchenruther et al., 
1999). Among these studies, Liu et al. (2007) determined the urban pollution periods following air mass back trajectories, and found that aerosol hygroscopicity was due to higher water soluble mass fraction (averaged 44.8\%) and lower mass fraction of total Carbon (34.7\% in $\mathrm{PM}_{2.5}$ ). Kotchenruther et al. (1999) classified the periods by airflow patterns, result indicates that airflows consistently influenced by anthropogenic sources show less scattered data at high $\mathrm{RH}$, the mean total carbon as percentage of total aerosol mass and that of sulfate mass are $49.8 \%$ and $38.6 \%$, with $f(80 \%$, $550 \mathrm{~nm})=2.1 \pm 0.4$ averagely.

\subsubsection{Special pollution episodes}

Under significant influence of urban pollution, we distinguish two main episodes (in the morning of 11 May and on 15 May, respectively) of which aerosols hydrophilicity and its effects on scattering coefficient are relatively higher with measured mean hygroscopic growth factor $f(\mathrm{RH}=80 \%)$ of 2.33-2.48 (green circles in Fig. 5). Detailed descriptions of experimental processes during those two days are as follows.

There are three hygroscopic growth experiments on 11 May. During the first experiment (began at 07:45 LST, and ended at 12:30 LST), aerosol scattering hygroscopic growth factor $f(\mathrm{RH})$ gradually enhances with $\mathrm{RH}$ increase from $38.0 \%$ to $91 \%$, and $f(\mathrm{RH}=80 \%)$ value of 2.51 . The second experiment (began at 15:40 LST and ended at 1820 LST) and the third experiment (from 19:05 LST to 22:30 LST) result in approximately same values of hygroscopic growth factor, $f(\mathrm{RH}=80 \%)=1.31$ and $f(\mathrm{RH}=80 \%)=1.33$ respectively. During the first experiment, measured dry aerosol scattering coefficients indicates mean dry scattering coefficient of about 211.2 $\mathrm{Mm}^{-1}$ with standard deviation of $96.8 \mathrm{Mm}^{-1}$; the observation site prevails southerly wind (averagely $1.85 \mathrm{~m} \cdot \mathrm{s}^{-1}$ ) with gradually change of wind direction to northerly strong blow (averagely $3.12 \mathrm{~m} \cdot \mathrm{s}^{-1}$ ) in the afternoon, and the dry scattering coefficient decreases to $102.5 \mathrm{Mm}^{-1}$. This suggests that aerosol types over observation site along air movement are physically and chemical distinct. Therefore, 24-h averaged chemical composition representing daily average condition seems to be insufficient to provide accurate explanation on the relationship between $f(\mathrm{RH})$ and chemical compounds.

Experiments (from 10:35 LST to 22:30 LST) performed on 15 May all show high $f(\mathrm{RH}=80 \%)$ of 2.56 in daytime and relatively lower value of 1.96 at night. Corresponding scattering coefficients are $379.3 \mathrm{Mm}^{-1}$ and $310.0 \mathrm{Mm}^{-1}$, respectively. Meteorologically, the site is characterized by weak southerly and relative high ambient temperature $\left(26.5^{\circ}\right.$ averagely), and low relative humidity ( $31.4 \%$ averagely), so that there is no evidence change of synoptic of weather condition with respect to 72-h back trajectories. Scattering closure calculations performed by the two methods indicate good consistency with measured scattering coefficient. High mass concentration of organic matter $\left(32.1 \mu \mathrm{g} \cdot \mathrm{m}^{-3}\right.$ in $\left.\mathrm{PM}_{2.1}\right)$ may play certain positive role in aerosol particle absorbing waters as discussed in Sect. 3.5.

\subsection{Scattering hygroscopic growth function}

Large variations of aerosols water absorbing ability appear among different dominant aerosols types, and fitting aerosols hygroscopic growth trends in dust, clean, urban pollution and special cases periods are shown in Fig. 5. Aerosols hygroscopic growth functions are obtained from Eq. (2), and used for monotonic growth illustration (Kotchenruther et al., 1998, 1999; Carrico et al., 2003; Magi et al., 2003; Liu et al., 2007). The parameters of (a) and (b) are described in Table 4. Both (a) and (b) seem to be undergone a sharply increase from dust particles $(a=0.64, b=5.17)$ to pollutant pe$\operatorname{riod}(\mathrm{a}=2.30, \mathrm{~b}=6.27)$

\subsection{Influence of organic compounds on aerosol hygroscopicity}

Water soluble inorganic ions and organic carbon matter are key factors directly correlated to aerosols water absorbing abilities as reported by (Virkkula et al., 1999; Malm et al., 2005). To characterize the influence of chemical compounds on hygroscopic properties of aerosols, ratio of OMC to AS is used, and Fig. 6 displays relationship between OMC/AS with $f(\mathrm{H}=80 \%)$ for the measurements. As many previous studies indicates, organic matter generally serve as hydrophobic compounds in water absorbing process of aerosol particles, however, large variations still exist for different weather conditions. During the urban pollutant episodes, aerosol hygroscopic capacity is gradually inhibited with increasing proportion of hydrophobic organic carbon matter, which might be originated from or mixed by urban anthropogenic emitted pollutant such as industrial and traffic activities. While in clean periods, plants released active carbon organics might sever as positive factor (such as surfactant) to promote inorganic salt to absorb water, as shown (Fig. 6), and laboratory studies carried by Choi et al. (2002), which show that malonic acid and citric acid, behaving as non-deliquescent species in single particle studies, caused Ammonium Sulfate particles to absorb a significant amount of water before deliquescence.

On 15 May, daily averaged OC mass concentration in $\mathrm{PM}_{2.1}$ is $20.54 \mu \mathrm{g} \cdot \mathrm{m}^{-3}$, increased of about $24.9 \%$ comparable to mean value of other periods, and OMC/AS ratio is 2.89 , while $f(\mathrm{RH}=80 \%)$ oppositely enhance to 2.21 averagely, this result has great disparity with many previous studies. The "closure" analysis by IMPROVE method indicated that the data of aerosol chemical compositions and measured scattering coefficients for the day are in quite good consistency, with the measurement and calculated aerosol scattering coefficient for dry aerosols are $396.5 \mathrm{Mm}^{-1}$, $341.0 \mathrm{Mm}^{-1}$, respectively. With such strong hygroscopic feature on 15 May 15, we speculate that organic matter 
Table 4. Curve-fitting parameters in different aerosol dominant episodes in terms of Eq. (2).

\begin{tabular}{llll}
\hline Classification & $\mathrm{a}$ & $\mathrm{b}$ & Reference \\
\hline Dust & $0.64 \pm 0.04$ & $5.17 \pm 0.4$ & \\
Clean & $1.20 \pm 0.06$ & $6.07 \pm 0.27$ & This work \\
pollutant & $2.30 \pm 0.03$ & $6.27 \pm 0.10$ & \\
Plume & $0.18 \pm 0.02$ & $6.11 \pm 0.43$ & Kotchenruther \\
Regional haze & $0.31 \pm 0.05$ & $5.08 \pm 0.11$ & et al. (1998) \\
Urban & 2.06 & 3.60 & \\
Mixed & 3.26 & 3.85 & Liu et al. (2007) \\
Marine & 4.92 & 5.04 & \\
\hline
\end{tabular}

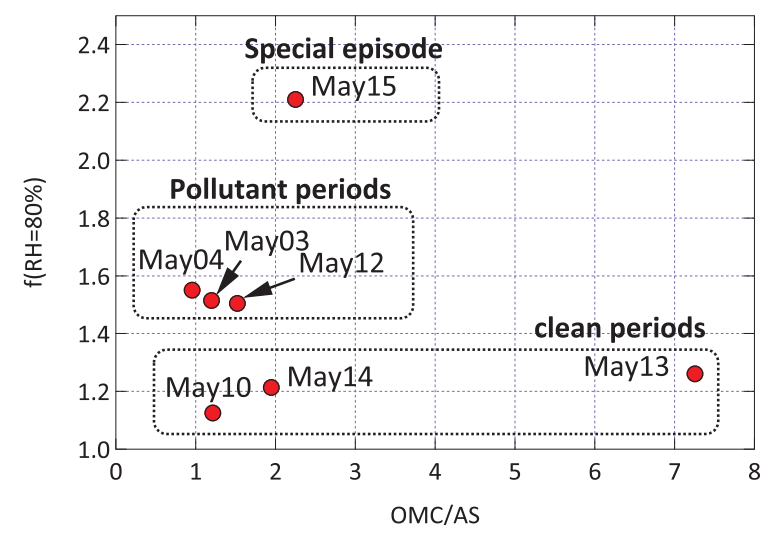

Fig. 6. Relationship between $f(\mathrm{RH}=80 \%)$ and value of $\mathrm{OMC} /\left(\mathrm{NH}_{4}\right)_{2} \mathrm{SO}_{4}$.

might havea complex interaction with inorganic salt which enhanced the hygroscopic growth of aerosols as suggested by Saxena et al. (1995) for the non-urban area. Cruz et al. (2000) also pointed out that the organic portion was observed to enhance the water uptake of the $\left(\mathrm{NH}_{4}\right)_{2} \mathrm{SO}_{4}$-organic aerosol systems by as much as a factor of 2-3 for particles consisting of $80 \%$ organic acids. Another result reported by Garland et al. (2007) on relative humidity dependence of light extinction in Organic-ammonium sulfate mixing aerosols, indicated that $f \mathrm{RH}_{\mathrm{ext}}(80 \% \mathrm{RH}$, dry) (the ratio of measured extinction coefficient at $\mathrm{RH}=80 \%$ to at $\mathrm{RH}<10 \%$ ) was about 2.15 while wt $\%$ of organic species reached $50 \%$ for dry mean optical diameter of $0.35 \mu \mathrm{m}$. The mixing state and interactions between sulfate and nitrate with coarse particle (mass concentration of $131 \mu \mathrm{g} \cdot \mathrm{m}^{-3}$ ) might also play a crucial role in aerosol hygroscopicity enhancement process. Nevertheless, present chemical composition data could not provide more satisfactory explanations, and further field experiments and information on organic compounds are needed to provide insights into schematics of organic and inorganic interaction.

\section{Conclusions}

Aerosols scattering hygroscopic growth experimental study over rural area near Beijing mega-city through analysis of key meteorological parameters and aerosols chemical composition, results in smooth and monotonic growth features associated with increasing RH in most of observation periods. Experimental data allow categorizing pollution episodes in three different cases (clean, dust, urban pollution) in accordance with aerosols mass concentrations and chemical compositions variations. (1) In the "clean" period, aerosols hygroscopic growth factor $f(\mathrm{RH}=80 \%)$ is $1.31 \pm 0.03$, higher than the results report by Yan et al. (2008) in rural area of North China (1.2), and lower than that of Koloutsou-Vakakis et al. (2001) measured in Northern Hemisphere continental site (1.4-1.5) and Carrico et al. (2000) in Sagres Portugal (1.69 \pm 0.16$)$. (2) During the dust episode, $f(\mathrm{RH}=80 \%)=1.2 \pm 0.02$, more lower than observational experiment result (1.73-2.20) obtained by Kim et al. (2006) The mixing effect of dust particles with sulfate, nitrate and sea-salt aerosols may be a plausible explanation of results divergence. (3) During urban pollutant phase, measured aerosol hygroscopic growth factor $f(\mathrm{RH}=80 \%)$ is $1.57 \pm 0.02$, lower than values of $2.04 \pm 0.28$ in southern coast area of China, 1.7-2.0 in Yangtze delta region and $1.81 \pm 0.37-2.30 \pm 0.24$ in East coast of the United States.

Generally, the $f(\mathrm{RH}=80 \%)$ is declining with increase of OMC/AS during urban pollutant episode, as many previous works showed; however, an interesting phenomena of high ratio of OMC/AS (2.89) in $\mathrm{PM}_{2.1}$ and high $f(\mathrm{RH}=80 \%)=2.21$ was observed on 15 May. Well consistency of scattering closure results and running condition of two nephelometers suggested existence of positive effect of organic particles on aerosol absorbing water. Through present experimental study, organic matter seems to importantly contribute to uncertainties of aerosols hygroscopic properties as well as the variations of hygroscopic growth. Facing this complexity, further experimental long-term study associated with specific modeling analysis on the relationship between organic compounds and aerosols hygroscopicity will be done in near future to thoroughly understand such physico-chemical process.

Acknowledgements. The authors thank Ding Guoan and the staff of the meteorological station for giving us great help during the observations. Their works and professional dedication are greatly respected and appreciated. This work is supported by the NSFC project (40675009) and NSFC(40433008) and the National Key Basic Research project (2006CB403701), and partly supported by the project (KZCX2-YW-205).

Edited by: A. Petzold 


\section{References}

Aklilu, Y., Mozurkewich, M., Prenni, A. J., et al.: Hygroscopicity of particles at two rural, urban influenced sites during Pacific 2001: Comparison with estimates of water uptake from particle composition, Atmos. Environ., 40(15), 2650-2661, 2006.

Berg, O. H., Swietlicki, E., and Krejci, R.: Hygroscopic growth of aerosol particles in the marine boundary layer over the Pacific and Southern Oceans during the First Aerosol Characterization Experiment (ACE 1), J. Geophys. Res.-Atmos., 103(D13), 16535-16545, 1998.

Bergin, M. H., Cass, G. R., Xu, J., et al.: Aerosol radiative, physical, and chemical properties in Beijing during June 1999, J. Geophys. Res., 106(D16), 17969-17980, 2001.

Bohren, C. F. and Huffman, D. R.: Absorption and scattering of light by small particles, Wiley, New York, 1983.

Carrico, C. M., Kreidenweis, S. M., Malm, W. C., et al.: Hygroscopic growth behavior of a carbon-dominated aerosol in Yosemite National Park, Atmos. Environ., 39(8), 1393-1404, 2005.

Carrico, C. M., Kus, P., Rood, M. J., et al.: Mixtures of pollution, dust, sea salt, and volcanic aerosol during ACE-Asia: Radiative properties as a function of relative humidity, J. Geophys. Res., 108(D23), 8650, doi:10.1029/2003JD003405, 2003.

Carrico, C. M., Rood, M. J., and Ogren, J. A.: Aerosol light scattering properties at Cape Grim, Tasmania, during the First Aerosol Characterization Experiment (ACE 1), J. Geophys. Res., 103(D13), 16565-16574, 1998.

Carrico, C. M., Rood, M. J., Ogren, J. A., et al.: Aerosol Optical properties at Sagres, Portugal during ACE-2, Tellus B, 52(2), 694-715, 2000.

Chan, C. Y., Xu, X. D., Li, Y. S., et al.: Characteristics of vertical profiles and sources of $\mathrm{PM}_{2.5}, \mathrm{PM}_{10}$ and carbonaceous species in Beijing, Atmos. Environ., 39(28), 5113-5124, 2005.

Charlson, R. J., Langner, J., Rodhe, H., et al.: Perturbation of the Northern Hemisphere radiative balance by backscattering from anthropogenic sulfate aerosols*, Tellus B, 43(4), 152-163, 1991.

Chen, L. Y., Jeng, F. T., Chen, C. C., et al.: Hygroscopic behavior of atmospheric aerosol in Taipei, Atmos. Environ., 37(15), 20692075, 2003.

Choi, M. Y. and Chan, C. K.: The Effects of Organic Species on the Hygroscopic Behaviors of Inorganic Aerosols, Environ. Sci. Technol., 36(11), 2422-2428, 2002.

Covert, D. S., Charlson, R. J., and Ahlquist, N. C.: A study of the relationship of chemical compositon and humdity to light scattering by aerosols, J. Appl. Meteorol., 11, 968-976, 1972.

Crumeyrolle, S., Gomes, L., Tulet, P., Matsuki, A., Schwarzenboeck, A., and Crahan, K.: Increase of the aerosol hygroscopicity by cloud processing in a mesoscale convective system: a case study from the AMMA campaign, Atmos. Chem. Phys., 8, 6907-6924, 2008,

http://www.atmos-chem-phys.net/8/6907/2008/.

Cruz, C. N. and Pandis, S. N.: Deliquescence and Hygroscopic Growth of Mixed Inorganic-Organic Atmospheric Aerosol, Environ. Sci. Technol., 34(20), 4313-4319, 2000.

Day, D. E. and Malm, W. C.: Aerosol light scattering measurements as a function of relative humidity, J. Air Waste Manage., 50(5), 710-716, 2000.

Dinar, E., Taraniuk, I., Graber, E. R., et al.: Hygroscopic growth of atmospheric and model humic-like substances, J. Geophys. Res.-
Atmos., 112, D05211, doi:10.1029/2006JD007442, 2007.

Draxler, R. R. and Hess, G. D.: An overview of the HYSPLIT_4 modelling system for trajectories, dispersion, and deposition, Aust. Meteorol. Mag., 47(4), 295-308, 1998.

Duan, F., Liu, X., Yu, T., et al.: Identification and estimate of biomass burning contribution to the urban aerosol organic carbon concentrations in Beijing, Atmos. Environ., 38(9), 1275-1282, 2004.

Ferron, G. A., Karg, E., Busch, B., et al.: Ambient particles at an urban, semi-urban and rural site in Central Europe: hygroscopic properties, Atmos. Environ., 39(2), 343-352, 2005.

Garland, R. M., Ravishankara, A. R., Lovejoy, E. R., et al.: Parameterization for the relative humidity dependence of light extinction: Organic-ammonium sulfate aerosol, J. Geophys. Res.Atmos., 112, D19303, doi:10.1029/2006JD008179, 2007.

Gouesbet, G.: Generalized Lorenz-Mie theory and applications, Part. Part. Syst. Char., 11(1), 22-34, 1994.

Gysel, M., Crosier, J., Topping, D. O., Whitehead, J. D., Bower, K. N., Cubison, M. J., Williams, P. I., Flynn, M. J., McFiggans, G. B., and Coe, H.: Closure study between chemical composition and hygroscopic growth of aerosol particles during TORCH2, Atmos. Chem. Phys., 7, 6131-6144, 2007, http://www.atmos-chem-phys.net/7/6131/2007/.

Gysel, M., Weingartner, E., and Baltensperger, U.: Hygroscopicity of Aerosol Particles at Low Temperatures. 2. Theoretical and Experimental Hygroscopic Properties of Laboratory Generated Aerosols, Environ. Sci. Technol., 36(1), 63-68, 2002.

Hand, J. L. and Malm, W. C.: Review of the IMPROVE Equation for Estimating Ambient Light Extinction Coefficients-Final Report, 47, 2006.

Harris, J. M. and Kahl, J. D. W.: Analysis of 10-day isentropic flow patterns for Barrow, Alaska: 1985-1992, J. Geophys. Res., 99(D12), 25845-25855, 1994.

He, K., Yang, F., Ma, Y., et al.: The characteristics of $\mathrm{PM}_{2.5}$ in Beijing, China, Atmos. Environ., 35(29), 4959-4970, 2001.

Herich, H., Kammermann, L., Gysel, M., et al.: In situ determination of atmospheric aerosol composition as a function of hygroscopic growth, J. Geophys. Res.-Atmos., 113, D16213, doi:10.1029/2008JD009954, 2008.

Houghton, J. T., Ding, Y., Griggs, D. J., et al.: IPCC, 2001: Climate Change 2001: The Scientific Basis. Contribution of Working Group I to the Third Assessment Report of the Intergovernmental Panel on Climate Change, Cambridge University Press, Cambridge, 2001.

Kim, J., Yoon, S. C., Jefferson, A., et al.: Aerosol hygroscopic properties during Asian dust, pollution, and biomass burning episodes at Gosan, Korea in April 2001, Atmos. Environ., 40(8), 1550 1560, 2006.

Koloutsou-Vakakis, S., Carrico, C. M., Kus, P., et al.: Aerosol properties at a midlatitude Northern Hemisphere continental site, J. Geophys. Res., 106(D3), 3019-3032, 2001.

Kotchenruther, R. A. and Hobbs, P. V.: Humidification factors of aerosols from biomass burning in Brazil, J. Geophys. Res., 103(D24), 32081-32090, 1998.

Kotchenruther, R. A., Hobbs, P. V., and Hegg, D. A.: Humidification factors for atmospheric aerosols off the mid-Atlantic coast of the United States, J. Geophys. Res., 104(D2), 2239-2252, 1999.

Larson, S. M., Cass, G. R., Hussey, K. J., et al.: Verification of image processing based visibility models, Environ. Sci. Technol., 
22(6), 629-637, 1988.

Li-Jones, X., Maring, H. B., and Prospero, J. M.: Effect of relative humidity on light scattering by mineral dust aerosol as measured in the marine boundary layer over the tropical Atlantic Ocean, J. Geophys. Res., 103(D23), 31113-31121, 1998.

Liu, X., Cheng, Y., Zhang, Y., et al.: Influences of relative humidity and particle chemical composition on aerosol scattering properties during the 2006 PRD campaign, Atmos. Environ., 42(7), 1525-1536, 2007.

Magi, B. I. and Hobbs, P. V.: Effects of humidity on aerosols in southern Africa during the biomass burning season, J. Geophys. Res.-Atmos., 108(D13), 8495, doi:10.1029/2002JD002144, 2003.

Malm, W. C. and Day, D. E.: Estimates of aerosol species scattering characteristics as a function of relative humidity, Atmos. Environ., 35(16), 2845-2860, 2001.

Malm, W. C., Day, D. E., Carrico, C., et al.: Intercomparison and closure calculations using measurements of aerosol species and optical properties during the Yosemite Aerosol Characterization Study, J. Geophys. Res.-Atmos., 110, D14302, doi:10.1029/2004JD005494, 2005.

Malm, W. C., Day, D. E., Kreidenweis, S. M., et al.: Hygroscopic properties of an organic-laden aerosol, Atmos. Environ., 39(27), 4969-4982, 2005.

McMurry, P. H. and Zhang, X.: Issues in aerosol measurement for optics assessments, J. Geophys. Res.-Atmos., 101(D14), 1918919197, 1996.

Meszaros, E., Molnar, A., and Ogren, J.: Scattering and absorption coefficients vs. chemical composition of fine atmospheric aerosol particles under regional conditions in Hungary, J. Aerosol Sci., 29(10), 1171-1178, 1998.

Pagels, J., Strand, M., Rissler, J., et al.: Characteristics of aerosol particles formed during grate combustion of moist forest residue, J. Aerosol Sci., 34(8), 1043-1059, 2003.

Perry, K. D., Cliff, S. S., and Jimenez-Cruz, M. P.: Evidence for hygroscopic mineral dust particles from the Intercontinental Transport and Chemical Transformation Experiment, J. Geophys. Res., 109, D23S28, doi:10.1029/2004JD004979, 2004.

Qiu, J., Yang, L., and Zhang, X.: Characteristics of the imaginary part and single-scattering albedo of urban aerosols in northern China, Tellus B, 56(3), 276-284, 2004.

Randles, C. A., Russell, L. M., and Ramaswamy, V.: Hygroscopic and optical properties of organic sea salt aerosol and consequences for climate forcing, Geophys. Res. Lett., 31, L16108, doi:10.1029/2004GL020628, 2004.

Rissler, J., Swietlicki, E., Zhou, J., Roberts, G., Andreae, M. O., Gatti, L. V., and Artaxo, P.: Physical properties of the submicrometer aerosol over the Amazon rain forest during the wetto-dry season transition - comparison of modeled and measured CCN concentrations, Atmos. Chem. Phys., 4, 2119-2143, 2004, http://www.atmos-chem-phys.net/4/2119/2004/.

Santarpia, J. L., Gasparini, R., Li, R., et al.: Diurnal variations in the hygroscopic growth cycles of ambient aerosol populations, J. Geophys. Res., 110, D03206, doi:10.1029/2004JD005279, 2005.

Saxena, P., Hildemann, L. M., McMurry, P. H., et al.: Organics alter hygroscopic behavior of atmospheric particles, J. Geophys. Res., 100(D9), 18755-18770, 1995.

Shi, Z., Zhang, D., Hayashi, M., et al.: Influences of sulfate and nitrate on the hygroscopic behaviour of coarse dust particles, At- mos. Environ., 42(4), 822-827, 2007.

Sun, Y., Zhuang, G., Wang, Y., et al.: The air-borne particulate pollution in Beijing - concentration, composition, distribution and sources, Atmos. Environ., 38(35), 5991-6004, 2004.

Tang, I. N.: Chemical and size effects of hygroscopic aerosols on light scattering coefficients, J. Geophys. Res., 101(D14), 1924519250, 1996.

Turpin, B. J. and Lim, H. J.: Species contributions to $\mathrm{PM}_{2.5}$ mass concentrations: Revisiting common assumptions for estimating organic mass, Aerosol Sci. Tech., 35(1), 602-610, 2001.

Van De Hulst, H. C.: Light scattering by small particles, Courier Dover Publications, 160, 1981.

Virkkula, A., Van Dingenen, R., Raes, F., et al.: Hygroscopic properties of aerosol formed by oxidation of limonene, alpha-pinene, and beta-pinene, J. Geophys. Res., 104(D3), 3569-3580, 1999.

Vlasenko, A., Sjø̈gren, S., Weingartner, E., et al.: Generation of submicron Arizona test dust aerosol: Chemical and hygroscopic properties, Aerosol Sci. Tech., 39(5), 452-460, 2005.

Wang, Y., Zhuang, G., Tang, A., et al.: The evolution of chemical components of aerosols at five monitoring sites of China during dust storms, Atmos. Environ., 41(5), 1091-1106, 2007.

Wise, M. E., Surratt, J. D., Curtis, D. B., et al.: Hygroscopic growth of ammonium sulfate/dicarboxylic acids, J. Geophys. Res.Atmos., 108(D20), 4638, doi:10.1029/2003JD003775, 2003.

$\mathrm{Xu}$, J., Bergin, M. H., Yu, X., et al.: Measurement of aerosol chemical, physical and radiative properties in the Yangtze delta region of China, Atmos. Environ., 36(2), 161-173, 2002.

Yamato, M. and Tanaka, H.: Aircraft observations of aerosols in the free marine troposphere over the North Pacific Ocean: particle chemistry in relation to air mass origin, J.Geophys. Res., 99(D3), 5353-5377, 1994.

Yan, P., Pan, X., Tang, J., et al.: Hygroscopic growth of aerosol scattering coefficient: A comparative analysis between urban and suburban sites at winter in Beijing. Particuology, 7(1), 52-60, 2009.

Yan, P., Pan, X. L., Tang, J., et al.: An experimental study on the influence of relative humidity on the atmospheric aerosol scattering coeff icient at an urban site in Beijing, Acta Meteorol. Sin., 6(1), 11-119, 2008.

Yan, P., Tang, J., Huang, J., Mao, J. T., Zhou, X.J., Liu, Q., Wang, Z. F., and Zhou, H. G.: The measurement of aerosol optical properties at a rural site in Northern China, Atmos. Chem. Phys., 8, 2229-2242, 2008, http://www.atmos-chem-phys.net/8/2229/2008/.

Yang, F., He, K., Ye, B., Chen, X., Cha, L., Cadle, S. H., Chan, T., and Mulawa, P. A.: One-year record of organic and elemental carbon in fine particles in downtown Beijing and Shanghai, Atmos. Chem. Phys., 5, 1449-1457, 2005, http://www.atmos-chem-phys.net/5/1449/2005/.

Zhang, D. and Iwasaka, Y.: Nitrate and sulfate in individual Asian dust-storm particles in Beijing, China in Spring of 1995 and 1996, Atmos. Environ., 33(19), 3213-3223, 1999.

Zhang, D., Iwasaka, Y., Shi, G., et al.: Mixture state and size of Asian dust particles collected at southwestern Japan in spring 2000, J. Geophys. Res., 108(D24), 4760, doi:10.1029/2003JD003869, 2003.

Zhou, J., Swietlicki, E., Berg, O. H., et al.: Hygroscopic properties of aerosol particles over the central Arctic Ocean during summer, J. Geophys. Res.-Atmos., 106(D23), 32111-32123, 2001. 